\title{
The Officina Plantiniana as publishers and distributors of music, 1578-1600
}

\author{
Louisa Hunter-Bradley
}

Relatively little is known about the sale of printed books of polyphony in late sixteenthcentury Europe, including such details as the geographical spread of copies and how long individual titles remained available for sale. However, the sales records of the Officina Plantiniana, founded by Christophe Plantin (c. 1520-1589), provide unique information that illuminates these elusive questions. Although polyphonic music publication made up only a small percentage $(0.57 \%)$ of titles issued by Plantin, an investigation of the sales and dissemination of his music books, and of his firm's sales of music books published by others, provides important insights into the identities and methods of Plantin's agents and purchasers, his systems of distribution and sales and his strategy for pricing. ${ }^{1}$

This study provides an analysis of the records of Plantin's sales of polyphonic music between 1578 and 1600, complementing Henri Vanhulst's study of music sales between 1566 and $1578 .^{2}$ These years, which cover the period when Plantin produced editions of polyphony, are of particular interest. The primary sources analysed here are the firm's Journals, which contain the daily records of the business of printing and selling books. ${ }^{3}$ The entries in these annual Journals, arranged in chronological order, record details of the purchase or sale of books, paper and parchment, and the costs of commercial bookbinding carried out through the firm. ${ }^{4}$ A list of music sales by the Officina Plantiniana, compiled from these Journals, forms the basis for my analysis of sales numbers, geographical spread and trends or preferences in the repertory disseminated. ${ }^{5}$

The market for Plantin's music books reflected the trading connections of Antwerp. Access to the North Sea provided maritime routes to Baltic ports, the Iberian Peninsula and the Atlantic. Land routes connected Antwerp to Cologne and Paris to the east and southwest, and southwards to Frankfurt, Augsburg and Italy. Plantin cited this easy access to transport routes in a letter to Pope Gregory XIII (9 October 1574), in which he requested permission to set up his business in Antwerp. ${ }^{6}$

To reach European markets, Plantin primarily sold his books at major trading hubs, including the Frankfurt book fair: $42 \%$ of his choirbooks and $28 \%$ of his partbooks were sent directly to his Frankfurt warehouse. Moreover, he sent consignments to Cologne, served local markets within the Low Countries, and established strong trading relationships with other publishers and booksellers in centres such as Douai, Danzig, London and Rouen; many of these trading partners had left Antwerp following the siege of the city in 1585 and its forcible re-Catholicisation. ${ }^{7}$

Between 1578 and 1600, the Officina Plantinina published five choirbooks and nine collections of polyphonic vocal music in partbooks; details of these can be found in Table 12.6 in the Appendix. ${ }^{8}$ Through analysis of the Journals for this period, it is possible to identify 
total sales of 210 copies of Plantin's grand folio choirbooks and 2,279 separate sets of his partbooks. This difference in raw numbers shows that there was a much stronger market for partbook collections than for the specialised, prestigious and costly choirbooks.

\section{Destination of sales}

Table 12.1 summarises the geographical spread of the choirbooks, using broad areas based on those studied by Bowen and Imhof. ${ }^{9}$ Together with Figure 12.1, these figures demonstrate the wide geographical distribution of Plantin's polyphonic choirbooks despite the relatively few copies sold over a period of twenty-three years. Most of Plantin's choirbooks were sent to the Frankfurt book fair for onward sale. (Their final destinations will require a separate study.) Plantin sold many of his choirbooks where he was represented by his own bookshop, such as at Paris, or by an agent at a fair, as at Cologne. Cologne lay on the route to Frankfurt, and was itself a major marketplace for books. Some of the consignments for the Frankfurt fair were dropped off in Cologne. Leon Voet, the leading modern historian of Plantin's business, states that Plantin and his son-in-law Jan I Moretus (1543-1610), who would later inherit the business, 'seem regularly to have broken their journeys to talk business with Cologne booksellers over a drink' ${ }^{10}$ Smaller sales were made to a variety of destinations, including towns in the Low Countries such as Ath, Ghent, Kessel and Tournai, but also locations further afield, including cities under Spanish control such as Seville, Albergaria (in Portugal) and Veracruz (on the Gulf of Mexico), and Protestant cities such as Königsberg, a Hanseatic city on the Baltic Sea.

In some cases, the destination of sales reflected the composer's own connections. Alard du Gaucquier (c. 1534-1582) served Emperors Maximillian II and Rudolf II while residing in the Low Countries. It is not a surprise therefore that copies of his Quatuor missae (1581) were sold to local customers in Antwerp, Ath and Crespin, as well as being exported to centres further afield, including Seville and Königsberg, generally in one or two copies per location. However, most exemplars (sixteen copies, half of the total documented sales) were disseminated through the Frankfurt fair.

In contrast, the Quatuor missae (1583) of Jacobus de Kerle (c. 1531-1591) sold less well in the Low Countries. Following the early years of his career in the Low Countries, de Kerle spent most of his time working in Augsburg, Vienna and finally in Prague. It is therefore unsurprising that his Quatuor missae sold best in German-speaking lands. Of the twenty-eight documented sales of this collection, twenty-one were made in Frankfurt or Cologne. Twelve of the copies that passed through Cologne went to an agent, who then passed them to de Kerle in fulfilment of his contractual obligation to purchase twelve

Table 12.1 Geographical destination of Plantin's choirbook sales, 1578-1600

\begin{tabular}{ll}
\hline Geographical area & Percentage \\
\hline Low Countries & 17 \\
France & 15 \\
Germany/Habsburg territories & 14 \\
Frankfurt book fair & 42 \\
Iberia & 3 \\
Italy & 4 \\
Americas & 3 \\
Unidentified & 2 \\
\hline
\end{tabular}




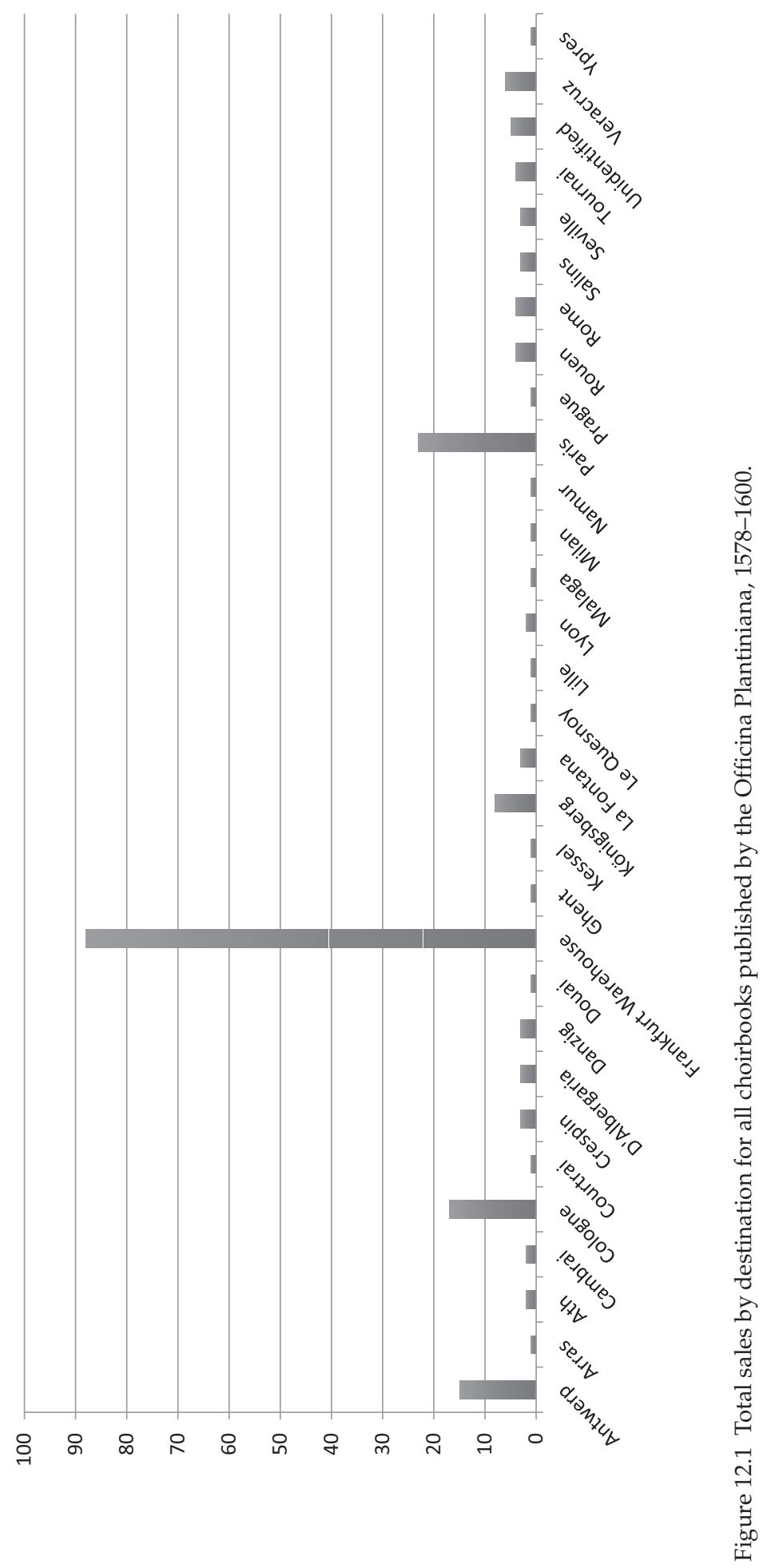


copies from Plantin. ${ }^{11}$ As with the masses by du Gaucquier, the remaining copies were sold to local destinations at an average of one to two copies each.

The Journal entries relating to sales of the Octo missae (1578) by George de La Hèle (15471586) are more complicated. Plantin's contract with La Hèle stipulated that the composer was to purchase forty copies of the choirbook. ${ }^{12}$ La Hèle did not meet this obligation, claiming difficulties due to a faltering political and financial climate. ${ }^{13}$ Indeed, the limited sales of Plantin's choirbooks subsequently suggest that this was an unrealistic obligation. The four books sent to La Hèle are not listed in the Journals, but appear in the Grand Livre (largeformat summary records including sales from the Journals, cash accounts and consignments to authors), dated 6 September 1578 and addressed to Tournai. ${ }^{14}$ Although these were never paid for, they are included in Figure 12.2 for the sake of completeness.

As with the choirbooks of du Gaucquier and de Kerle, most copies of La Hèle's masses were sold locally in the Low Countries, or to Plantin's agents in Paris and Frankfurt. Of particular interest in Figure 12.2 are the six copies sold to the Spanish settlement of Veracruz in Mexico. From 1570 onwards the Augustinian cleric Señor Alonso in Veracruz wanted to set up a trade relationship with Plantin, although Plantin had concerns regarding the risks and limited profitability of such ventures. ${ }^{15}$ Alonso's six copies of La Hèle's Octo missae were possibly sent on to a number of cathedrals recently established in Mexico, such as Mexico City's Catedral Metropolitana, the Catedral de San Cristóbal de las Casas or the Catedral de Mérida, Yucatán. Given that Plantin started publishing polyphonic music possibly to win favour with Philip II of Spain (and perhaps also to use up excess stocks of grand folio paper), it is not surprising that copies of his first polyphonic choirbook reached Veracruz, one of Philip II's outlying domains. ${ }^{16}$ Moreover, La Hèle was also the only composer printed by Plantin who subsequently worked in Philip's service.

These costly, prestigious choirbooks spread over a wide geographical area: approximately $80 \%$ of them were sold outside the Low Countries. Since these publications were usually bought by religious institutions or nobility, there was a limited opportunity for

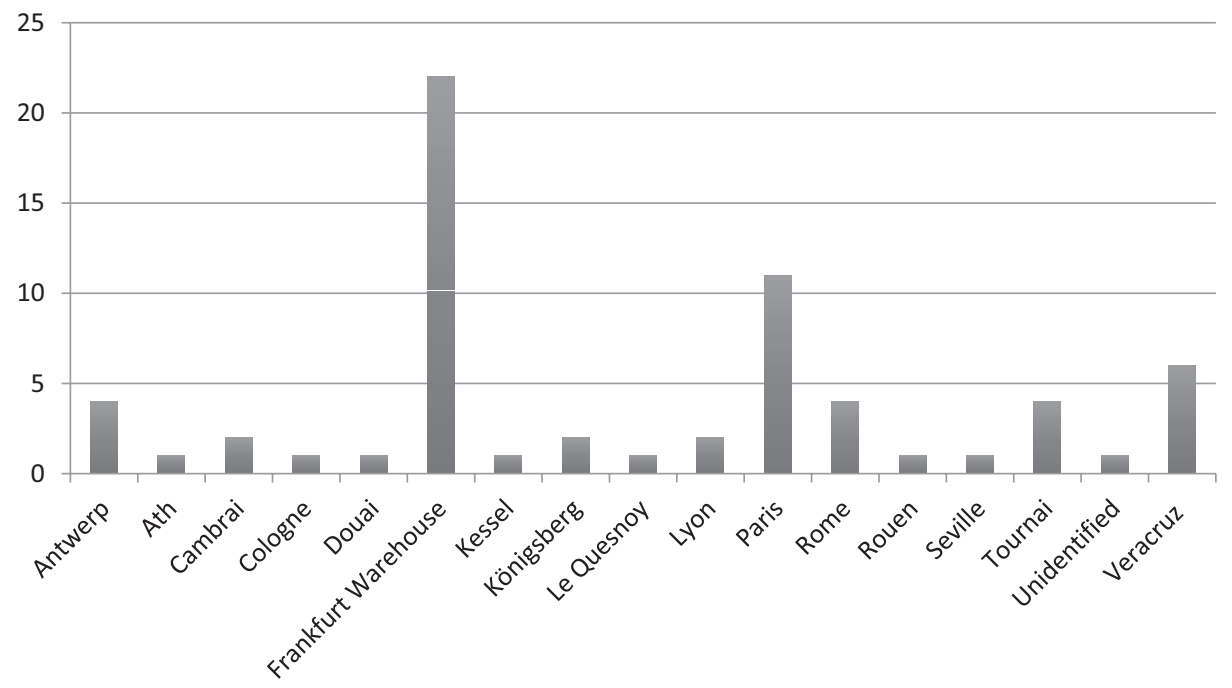

Figure 12.2 Sales by destination of La Hèle's Octo missae, 1578-1600. 
Table 12.2 Geographical destination of Plantin's partbook sales, 1578-1600

\begin{tabular}{lc}
\hline Geographical Area & Percentage \\
\hline Low Countries & 50 \\
France & 11 \\
Germany/Habsburg territories & 5 \\
Frankfurt book fair & 28 \\
Iberia & 0.3 \\
Italy & 0.7 \\
England & 3 \\
Unidentified & 2 \\
\hline
\end{tabular}

local sales. The higher prices of these deluxe editions also accounts for lower sales figures. The prices of these books are analysed in Table 12.3.

Table 12.2 and Figure 12.3 show that partbooks sold better in the local market of the Low Countries and Northern France; local consumption of partbooks accounts for $50 \%$ of total sales, as opposed to $17 \%$ for choirbooks. Approximately a quarter of total sales of partbooks were made via the Frankfurt fair, a much smaller proportion than for choirbooks. There are also differences in patterns of export: Plantin's partbooks were exported to England, but not to the Americas. As with the choirbooks, the Paris bookshop of Michel Sonnius, previously run by the Officina Plantiniana, purchased a large quantity of partbooks, predominantly of the Livre de mélanges (1585) by Claude Le Jeune (c. 1528/30-1600). Trade in partbooks with Douai - both Plantin's own publications and those he sold on behalf of other publishers was also very strong, chiefly through Plantin's trading relationship with Jean Bogard.

The copies of Le Jeune's Livre de mélanges travelled to other French centres alongside Paris; Le Jeune's French nationality probably determined the destination of sales. The three titles by Séverin Cornet (c. 1520-1582) which Plantin published in 1581 (Cantiones musicae, Madrigali and Chansons françoyses) sold in significantly lower numbers (208 partbook sets in total) in proportion to the other partbooks. Many copies of the four collections of chansons (1589-1591) by Andreas Pevernage (1542/3-1591) were exported to the London booksellers Ascanius de Renialme and Hans Wanteneel (sixty-seven sets of partbooks); these were the only copies of Plantin's polyphonic music publications to travel to England.

\section{Customers}

The sales records also reveal the occupations of typical purchasers of choirbooks and partbooks. While publishers often aimed to make books appeal to as wide an audience as possible, specific books might be published with a targeted audience in mind. A publisher's decisions about paper quality, format and book length would depend upon the potential clientele for the book. Owners and buyers of books came from many sectors: merchants, artisans, craftsmen, tradespeople, nobility and other booksellers. ${ }^{17}$

Figure 12.4 shows that the majority of Plantin's sales of choirbooks - besides sales to booksellers and envoys to the Frankfurt fair - were made to clerics. However, the Journals do not record any direct sales of choirbooks to cathedrals in the Low Countries. ${ }^{18}$ However, in several instances multiple choirbooks were sold in one transaction. Some of these were probably to booksellers' agents: on 10 September 1583, Servatius Mercus from Maastricht purchased copies of the four choirbooks that Plantin had published prior to this date, as well as two copies of Cornet's Cantiones to take to Königsberg. ${ }^{19}$ Other examples 

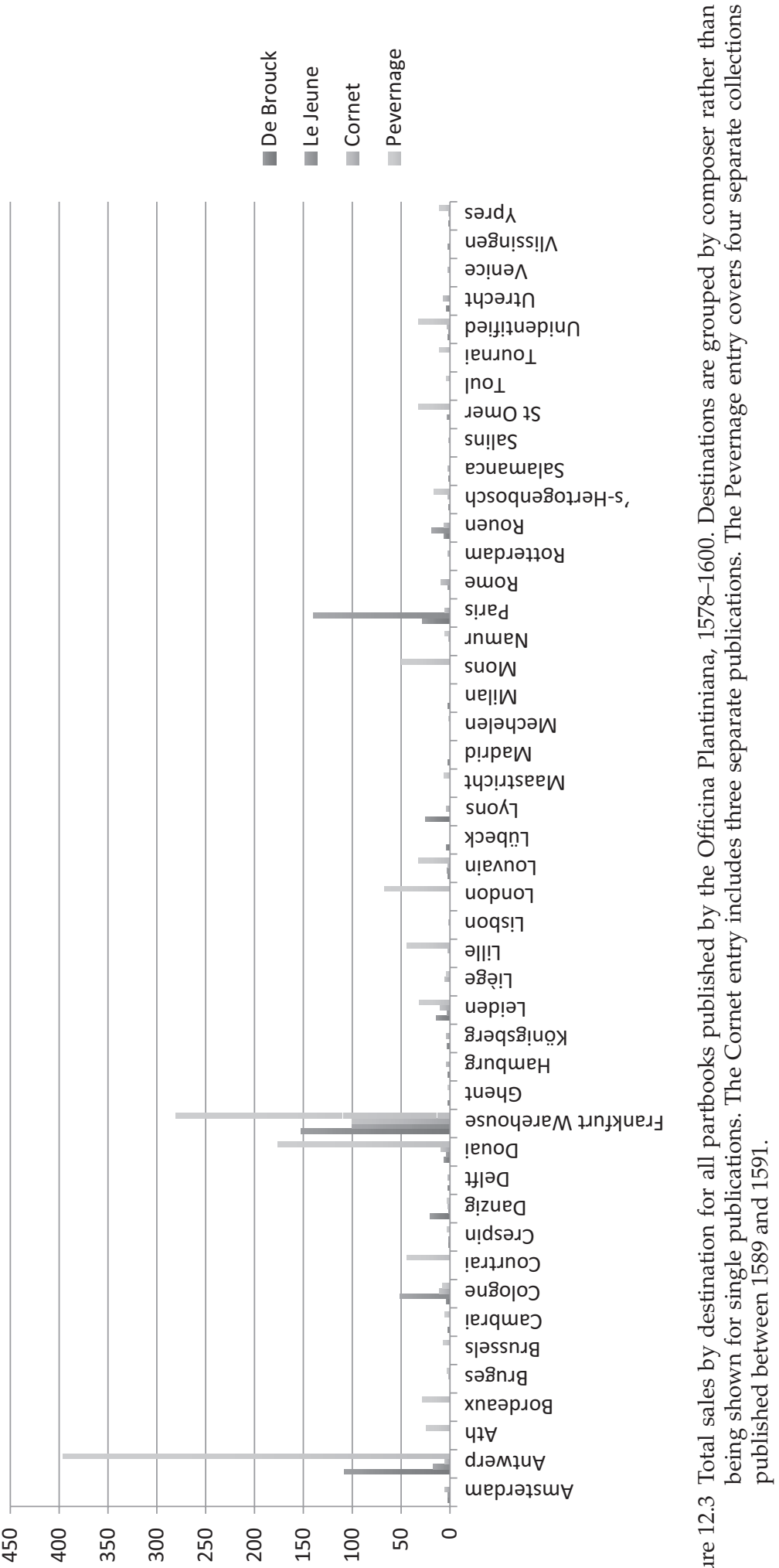

ֶֻ. 
of multiple book purchases were probably for a single institution, as, for example, the purchase made by Monsieur De Bellefontaine, the Abbot of Goailles in Salins, France. ${ }^{20}$ His purchase included three choirbooks, one partbook and two books manufactured by other publishers.

As with the choirbooks, the majority of Plantin's partbooks were sold to booksellers or sent to the Frankfurt fair (see Figure 12.5). Merchants or booksellers were more likely to buy the partbooks on speculation, but probably bought choirbooks with a particular client in mind. The predominantly secular content of the partbooks and appeal to a broader market meant that they had potentially greater sales than choirbooks, which were limited principally to large churches or cathedrals. Although the geographical reach of choirbooks was greater, they sold in fewer copies due to their specialist nature and greater cost.

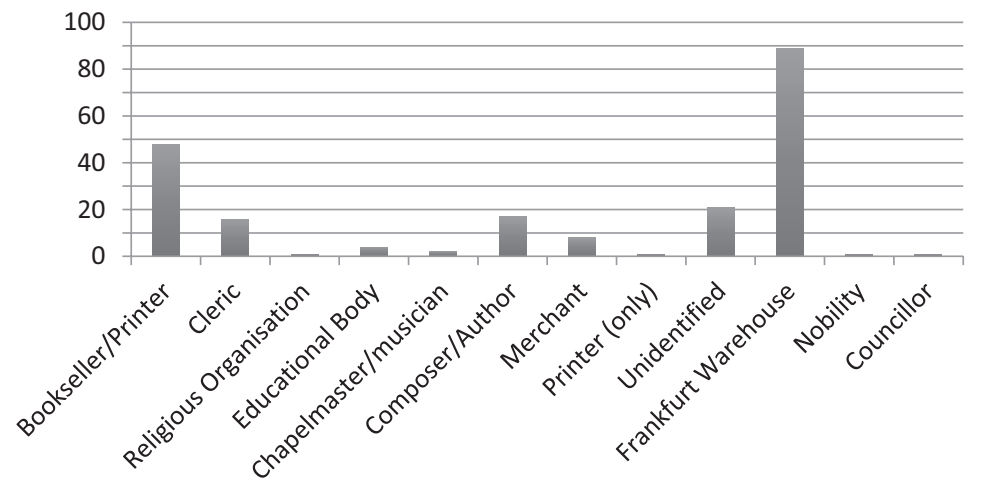

Figure 12.4 Customers for Plantin's choirbook publications, 1578-1600.

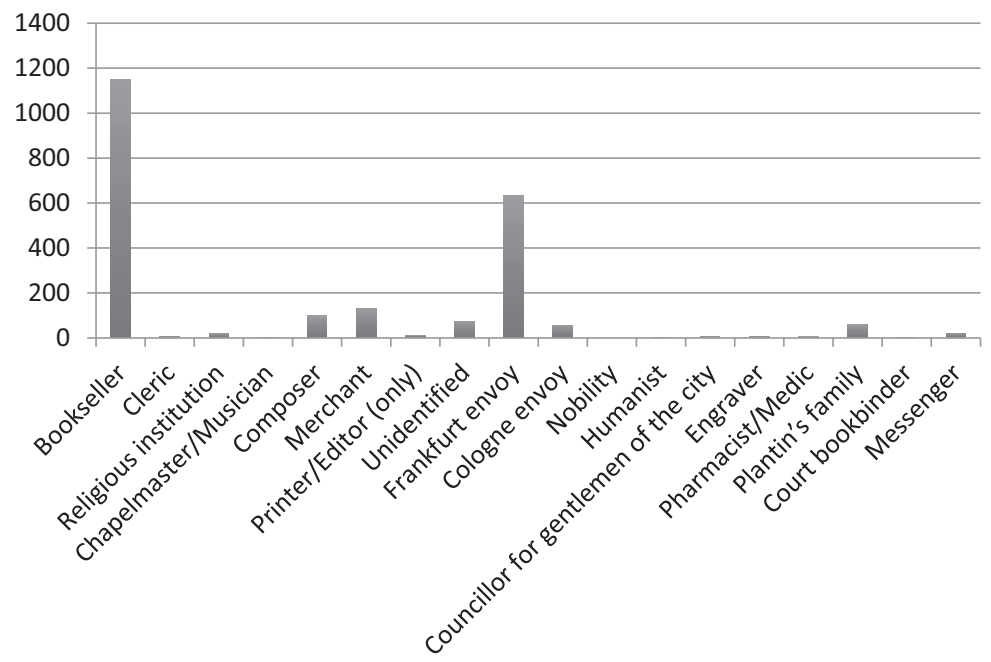

Figure 12.5 Profession of customers for Plantin's partbook publications, 1578-1600. 


\section{Price}

The price of a book depended on several factors: the quality and quantity of paper; the use of specialist type, illustrations or coloured inks; the workers required for production; and the strength of the market for this item. Due to the expert knowledge required to set music, as well as the larger formats required by choirbooks, these books were charged at prices similar to other specialised books. ${ }^{21}$ Royston Gustavson has shown, on the basis of a 1560 catalogue issued by the Nuremberg publishers Montanus and Neuber, that while books of theory and of monophonic music were priced at rates similar to generic printed editions, collections of 'polyphonic music attracted premium pricing, here of 1.5 times the generic price' ${ }^{22}$ The greater amount of work required in setting music was related to setting non-conventional type, but also involved what Stanley Boorman calls a double process: 'setting the music, and then setting the text correctly aligned with the music' ${ }^{23}$

From the Journal accounts, it is possible to observe some general patterns in the pricing of Plantin's publications. Although Voet states that discounts may have been offered to wholesalers (varying between $5 \%$ and $25 \%$ ), he notes that the account records hardly ever mention a discount. ${ }^{24}$ This is also true of the Journal entries for printed music.

Plantin allowed a discount of $5 \%-10 \%$ for small orders paid in cash. For more important transactions it might be much greater. In the seventeenth century the standardised rate of discounts for large orders was $20 \%$ for service books using black and red ink, and $25 \%$ for ordinary editions. ${ }^{25}$ Favoured wholesale customers of this kind receiving discounts for music books were Jacques Dupuis of Lyons, Jan Desserans and Ascanius de Renialme, who operated in London, Arnold Birckmann of Cologne and Michel Sonnius of Paris. Orders made by Philip II also attracted a discount. Merchants who occasionally exported books abroad were also able to obtain a discount. The principal Antwerp and Netherlands booksellers with whom Plantin did regular business certainly received a discount on credit accounts, at least in special circumstances. ${ }^{26}$

Table 12.3 shows the large variation in sale prices charged for Plantin's choirbooks. Prices in the Low Countries were charged in florins (fl.) and stuivers (st.), where twenty stuivers equalled one florin. A general pattern of pricing emerges when we calculate the price per sheet, the way by which the publications would have been costed. Plantin's first

Table 12.3 Range of prices for Plantin's choirbook publications, 1578-1600

\begin{tabular}{|c|c|c|c|c|c|}
\hline Choirbook $^{a}$ & Price range & $\begin{array}{l}\text { Typical } \\
\text { price }\end{array}$ & $\begin{array}{l}\text { Number } \\
\text { of pages }\end{array}$ & $\begin{array}{l}\text { Typical price } \\
\text { per page }\end{array}$ & $\begin{array}{l}\text { Typical price } \\
\text { per sheet }^{\mathrm{b}}\end{array}$ \\
\hline La Hèle & $4-25 \mathrm{fl}$. & $18 \mathrm{fl}$. & 540 & 0.67 st. & 1.34 st. \\
\hline De Monte, Benedicta es & 1 fl. 5 st. -1 fl. 10 st. & $1 \mathrm{fl} .10$ st. & 54 & 0.56 st. & 1.12 st. \\
\hline Du Gaucquier & 4-10 fl. & $6 \mathrm{fl}$. & 190 & 0.63 st. & 1.26 st. \\
\hline De Kerle & 5-10 fl. & $5 \mathrm{fl} .10 \mathrm{st}$. & 230 & 0.48 st. & 0.96 st. \\
\hline De Monte, Liber I & $16-25 \mathrm{fl}$. & $18 \mathrm{fl}$. & 720 & 0.5 st. & 1 st. \\
\hline
\end{tabular}

Some of these figures vary from those that are published by Stellfeld, who listed the sale price for the Du Gaucquier collection as 6 fl. 12 st. (p. 54) and the De Kerle as 9 fl. (p. 75). Stellfeld, Bibliographie.

asee Table 12.6 for full title information.

${ }^{b}$ These choirbooks are very large (La Hèle, approximately $550 \times 410 \mathrm{~cm}$; De Monte, Benedicta es, $550 \times$ $400 \mathrm{~cm}$; Du Gaucquier, $536 \times 385 \mathrm{~cm}$ ). The sheets were not printed with two pages on each side and then folded in half, as in folio format, but as whole sheets that were then bound along the edge (broadsheet or 'in plano' format, $1^{\circ}$ ). Despite this, the books were referred to as Grand folio books, even if they do not conform to what we understand as folio format today. 
choirbook was also the most expensive; prices dropped significantly towards the end of his production of choirbooks. ${ }^{27}$ The variation in prices between the choirbooks may reflect the fact that some were given away as gifts, as well as differences in quality of paper and the possible addition of binding for the higher priced publications. ${ }^{28}$ (Normally, prices were for unbound copies.)

Copies of La Hèle's Octo missae were most commonly sold for $18 \mathrm{fl}$; the only significantly discounted sale was the six copies sent to Veracruz at $4 \mathrm{fl}$. each. This low price may have been intended to encourage further sales in the Spanish colonies. In contrast, De Monte's single mass, Benedicta es, was generally sold at a price between $1 \mathrm{fl} .5 \mathrm{st}$. and $1 \mathrm{fl}$. 10 st. The price decreased from $1 \mathrm{fl} .10$ st. to $1 \mathrm{fl} .5$ st. over the period here analysed, except when sold to Frankfurt bookdealers, who were always charged at $1 \mathrm{fl} .10$ st. per copy, even for a consignment of thirty copies. ${ }^{29}$ None of the other choirbooks experienced a decline in the charged price over time.

The Journal figures suggest that higher prices were charged for bound copies or those prepared for special presentation. The Abbot of Wissembourg (Alsace) was charged $10 \mathrm{fl}$. each for the books of masses by Du Gaucquier and De Kerle. ${ }^{30}$ These copies were probably sold bound, and would thus also incur higher shipping costs besides the charge for binding itself. In one instance the Genoese merchants in Antwerp, Carolo Spinola and Giovanni Battista Grilli, were charged $20 \mathrm{fl}$. for the masses of Du Gaucquier and De Kerle bound together. Their copy of La Hèle's masses was charged at $25 \mathrm{fl}$. rather than the average price of $18 \mathrm{fl}$. , again suggesting either a higher grade of paper or the cost of binding. ${ }^{31}$

In two notable instances, the Frankfurt copies were charged at a marginally lower rate. In one case, the Du Gaucquier was sold at 5 fl. per copy rather than the average $6 \mathrm{fl}$; in another, four copies of De Monte's Missarum Liber I were charged at $16 \mathrm{fl}$. each, unlike all other sales of this book, which were charged at the regular price of $18 \mathrm{fl}$. per copy. Besides copies charged at a substantially higher rate, free copies were sometimes given to clerics: Plantin gave copies of the Du Gaucquier to a certain Fr. Andrea in Málaga and to the Abbot of Crespin. On 1 August 1586, Plantin sent copies of each of his polyphonic publications to that point to the Jesuit college in Antwerp, which had recently reopened after the end of the Spanish siege. ${ }^{32}$ The absence of any record of prices for this consignment of 201 titles, which also included liturgical works and humanist publications, suggests that these books were a gift from Plantin to the school.

The partbooks were charged at a significantly lower price per sheet than the choirbooks. This may be due to the use of cheaper paper, fewer woodcut initials and the fact that the compositors did not have to worry about the complex layout of choirbooks, in which the page-breaks had to be calculated precisely to coincide in each voice. Gustavson comments on how publishers balanced the financial risks of specific ventures; should a particular edition require only few sheets of paper, a firm could bear the danger posed by piracy or poor sales. ${ }^{33}$ The lower cost of producing the partbooks presumably made them a lesser financial risk for Plantin than the larger and more costly choirbooks. The purpose of the choirbooks was not necessarily to generate profit, but to create value from reputation and patronage. Moreover, partbooks contained more music by composers born or resident in Antwerp at the time of publication, which would predictably lead to greater local sales. ${ }^{34}$

As with the choirbooks, the prices of partbook sets also varied (see Table 12.4). The Livre de mélanges by Le Jeune shows more fluctuation than the others: Plantin's son-in-law Raphelengius received three copies for the price of one, and the Cologne bookseller Bernard Wolters received a copy for half price. In some instances, no price is listed at all. No price is given for the entry recording fifty copies of Le Jeune's Mélanges sent to Mylius in Cologne, a 
city often used as a way-station or deposit for the Frankfurt book fair. However, the prices listed in the Journals for the Frankfurt book fair consignments are clearly inconsistent. Pricing was generally provided for the Frankfurt consignments, though in many of other entries no figure is given. ${ }^{35}$

The records of sales of Le Jeune's Mélanges to Phalèse display some variation, due perhaps in part to the reciprocal arrangement between Plantin and Phalèse, who acted as agents for one another, and the consequent use of credit and other methods of accounting which are not immediately clear from the Journals. In the Journal, the prices charged to Phalèse for copies of Le Jeune's Mélanges fluctuate between $1 \mathrm{fl} .10$ st. and $3 \mathrm{fl}$. 10 st. per copy. However, over a period of eight years the average price per copy equates to the normal amount charged for this book. This relative stability of prices may indicate the steady commercial demand and larger market for partbook editions. The prices charged for Le Jeune's Mélanges also seem to correlate with the buying-power of the purchaser. While some booksellers were charged marginally less than the average price, nobility or councilmen were sometimes charged more: for example, the Mayor of Antwerp and the Jesuits in Danzig were charged 3 fl. per copy. Alternatively, this might once again also reflect the added cost of binding. Other notable examples of higher prices charged include a copy of the De Brouck sold to the Genoese merchants, Grilli and Spinola, at more than three times the average price. Their copy of the Le Jeune was also more than double the normal price.

The prices charged for the chansons of Cornet show the smallest variation, usually between $2 \mathrm{fl} .5$ st. and $2 \mathrm{fl} .15$ st., with one major exception: a discounted copy to the Abbot of Goailles, near Salins-les-Bains. However, the abbot was charged the regular amount or more for his copies of Plantin's choirbooks. The prices charged for the Pevernage chansons were likewise consistent. Unlike the slightly inflated prices charged to rich purchasers of Le Jeune's Mélanges, city councillors or similar were charged slightly less than the average for the chansons of Pevernage, who was based in Antwerp himself.

On rare occasions, no price is given; these entries therefore have not been included in Tables 12.4 and 12.5. Copies sent to Frankfurt were charged at the standard retail price. In some instances, no prices are noted, as in single occasions for Phalèse (Antwerp), Boulet (Lille), Bogard (Douai), Pierre Moretus (Antwerp) and fifty-six copies sent to Plantin's

Table 12.4 Range of prices for Plantin's partbook publications, 1578-1600

\begin{tabular}{|c|c|c|c|c|c|}
\hline Partbook $^{\mathrm{a}}$ & Price range & $\begin{array}{l}\text { Typical } \\
\text { price }\end{array}$ & $\begin{array}{l}\text { Total number of pages } \\
\text { per partbook set }\end{array}$ & $\begin{array}{l}\text { Typical } \\
\text { price per } \\
\text { page }\end{array}$ & $\begin{array}{l}\text { Typical } \\
\text { price per } \\
\text { sheet }^{b}\end{array}$ \\
\hline De Brouck & $1 \mathrm{fl} .-3 \mathrm{fl} .18$ st. & 1 fl. 2 st. & 354 & 0.06 st. & 0.48 st. \\
\hline Cornet 1-3 & $\begin{array}{l}11 \text { 1/2 st. }-2 \text { fl. } \\
15 \text { st. }\end{array}$ & 2 fl. 5 st. & $\begin{array}{l}\text { (1) cantiones } 174 \\
\text { (2) madrigals } 260 \\
\text { (3) chansons } 176\end{array}$ & $\begin{array}{l}0.26 \text { st. } \\
0.17 \text { st. } \\
0.26 \text { st. }\end{array}$ & $\begin{array}{l}2.08 \mathrm{st} . \\
1.38 \mathrm{st} \\
2.08 \mathrm{st}\end{array}$ \\
\hline Le Jeune & $\begin{array}{l}1 \mathrm{fl} .2 \text { st. }-4 \mathrm{fl} . \\
18 \text { st. }\end{array}$ & $2 \mathrm{fl} .10 \mathrm{st}$. & 702 & 0.07 st. & 0.56 st. \\
\hline Pevernage 1-3 & 10 st. -20 st. & $10 \mathrm{st}$. & $\begin{array}{l}\text { (1) } 90 \\
\text { (2) } 80 \\
\text { (3) } 80\end{array}$ & $\begin{array}{l}0.11 \text { st. } \\
0.125 \text { st. } \\
0.125 \text { st. }\end{array}$ & $\begin{array}{l}0.88 \text { st. } \\
1 \text { st. } \\
1 \text { st. }\end{array}$ \\
\hline Pevernage 4 & 15 st. -30 st. & 15 st. & 90 & 0.17 st. & 1.38 st. \\
\hline
\end{tabular}

Range of prices and page numbers do not appear in Stellfeld's Bibliographie. The way in which details are listed for each piece varies substantially. aSee Table 12.6 for full title information. ${ }^{\mathrm{b}} 1$ sheet $=8$ pages (quarto). 
Table 12.5 Range of prices for non-Officina Plantiniana music partbooks sold by Plantin and his heirs, 1578-1600

\begin{tabular}{|c|c|c|c|c|c|c|}
\hline Title & Format & $\begin{array}{l}\text { Total } \\
\text { number } \\
\text { of pages }^{\text {a }}\end{array}$ & Price range & Typical price & $\begin{array}{l}\text { Typical } \\
\text { price per } \\
\text { page }\end{array}$ & $\begin{array}{l}\text { Typical } \\
\text { price } \\
\text { per } \\
\text { sheet }\end{array}$ \\
\hline $\begin{array}{l}\text { La fleur des } \\
\text { chansons } \\
\text { d'Orlande de } \\
\text { Lassus }\end{array}$ & 5 vol. quarto & $\begin{array}{l}- \text { (Parts } \\
\text { missing }) \\
436\end{array}$ & $\begin{array}{l}\text { 1592: } 1 \text { fl. } 8 \text { st. } \\
\text { 1596: } 1 \text { fl. } 5 \text { st. } \\
\text { - } 1 \text { fl. } 15 \text { st. }\end{array}$ & $\begin{array}{l}\text { 1592: } 1 \text { fl. } 8 \text { st. } \\
\text { 1596: } 1 \text { fl. } 10 \text { st. }\end{array}$ & $\begin{array}{l}? \\
0.07 \text { st. }\end{array}$ & $\begin{array}{l}? \\
1.12 \text { st. }\end{array}$ \\
\hline $\begin{array}{l}\text { Harmonia } \\
\text { celeste }\end{array}$ & 6 vol. quarto & $\begin{array}{l}-(\text { Parts } \\
\text { missing }) \\
376\end{array}$ & $\begin{array}{l}\text { 1583: } 1 \mathrm{fl} \\
15891 \mathrm{fl} .4 \mathrm{st} .\end{array}$ & $\begin{array}{l}\text { 1583: } 1 \mathrm{fl} \\
15891 \mathrm{fl} .4 \mathrm{st} .\end{array}$ & $\begin{array}{l}? \\
0.065 \text { st. }\end{array}$ & $\begin{array}{l}? \\
1.04 \text { st. }\end{array}$ \\
\hline $\begin{array}{l}\text { Il lauro verde } \\
\text { madrigali }\end{array}$ & 6 vol. quarto & 240 & 15 st. & 15 st. & 0.065 st. & 1.04 st. \\
\hline $\begin{array}{l}\text { Melodia } \\
\text { olympica }\end{array}$ & 6 vol. quarto & $\begin{array}{l}374 \\
380\end{array}$ & $\begin{array}{l}\text { 1591: } 1 \text { fl. } 4 \text { st. } \\
\text { - } 1 \text { fl. } 5 \text { st. } \\
\text { 1594: } 1 \text { fl. } 5 \text { st. } \\
\text { - } 1 \text { fl. } 6 \text { st. }\end{array}$ & $\begin{array}{l}\text { 1591: } 1 \mathrm{fl} 5 \text { st. } \\
\text { 1594: } 1 \text { fl. } 5 \text { st. }\end{array}$ & $\begin{array}{l}0.065 \text { st. } \\
0.065 \text { st. }\end{array}$ & $\begin{array}{l}1.04 \text { st. } \\
1.04 \text { st. }\end{array}$ \\
\hline Musica divina & 6 vol. quarto & $\begin{array}{l}376 \\
376 \\
376 \\
376\end{array}$ & $\begin{array}{l}\text { 1583: } 1 \mathrm{fl}-2 \\
\text { fl. } 2 \text { st } \\
\text { 1588: } 1 \mathrm{fl} .-1 \mathrm{fl} . \\
6 \text { st. } \\
\text { 1591: } 1 \mathrm{fl} .2 \text { st. } \\
\text { - } 1 \text { fl. } 10 \text { st. } \\
\text { 1595: } 1 \text { fl. } 2 \text { st. } \\
\text { - } 1 \text { fl. } 10 \text { st. }\end{array}$ & $\begin{array}{l}\text { 1583: } 1 \mathrm{fl} \\
\text { 1588: } 1 \mathrm{fl} .2 \text { st. } \\
\text { 1591: } 1 \text { fl. } 2 \text { st. } \\
\text { 1595: } 1 \mathrm{fl} .2 \text { st. } \\
\text { and } 1 \mathrm{fl} .4 \text { st. in } \\
\text { equal amounts. }\end{array}$ & 0.06 st. & 0.96 st. \\
\hline $\begin{array}{l}\text { Pratum } \\
\text { Musicum }\end{array}$ & 1 vol. folio & 184 & $\begin{array}{l}1 \mathrm{fl} .3 \text { st. }-1 \mathrm{fl} . \\
16 \text { st. }\end{array}$ & $1 \mathrm{fl} .10 \mathrm{st}$. & 0.16 st. & $1.28 \mathrm{st}$. \\
\hline $\begin{array}{l}\text { Symphonia } \\
\text { angelica }\end{array}$ & 6 vol. quarto & $\begin{array}{l}376 \\
376 \\
376\end{array}$ & $\begin{array}{l}\text { 1585: } 1 \text { fl. } 2 \text { st. } \\
-1 \mathrm{fl} .6 \text { st. } \\
\text { 1590: } 1 \text { fl. } 2 \text { st. } \\
-1 \mathrm{fl} .5 \text { st. } \\
\text { 1594: } 1 \mathrm{fl} .2 \text { st. } \\
\text { - } 1 \mathrm{fl} .4 \text { st. }\end{array}$ & $\begin{array}{l}\text { 1585: } 1 \mathrm{fl} .2 \text { st. } \\
\text { and } 1 \text { fl. } 4 \text { st. in } \\
\text { equal amounts. } \\
\text { 1590: } 1 \text { fl. } 2 \text { st. } \\
\text { 1594: } 1 \text { fl. } 4 \text { st. }\end{array}$ & 0.06 st. & $0.96 \mathrm{st}$. \\
\hline
\end{tabular}

${ }^{a}$ Number of pages and format taken from RISM.

son-in-law Jan Spirinck, who represented the Officina Plantiniana in Hamburg (1577-1583) and Antwerp (from 1588). ${ }^{36}$ Prices for the Pevernage chansons increased marginally and consistently towards the end of the period here studied. This is the opposite of what happened with the grand folio sheets of De Monte's Benedicta es, but might reflect continued demand for the diminishing supply of copies, as the Officina Plantiniana did not reprint any of their music books (see Figure 12.6).

\section{Longevity of sales}

This study also suggests some answers to a question often asked by scholars of music printing: how long did music books remain available for sale? Did all copies sell rapidly after publication, or did sales persist over a long period? With regard to sixteenth-century Italy, Stanley Boorman states that 'there is much evidence to suggest that music-sellers and publishers had copies available for sale many years after publication'. ${ }^{37}$ Royston 
De Brouck Sales by Year (396)

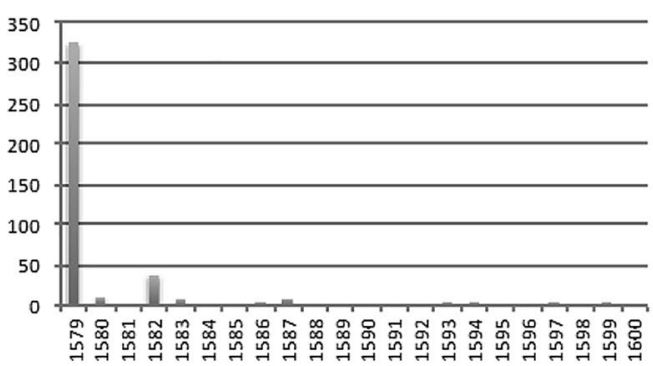

Le Jeune Sales by Year (349)

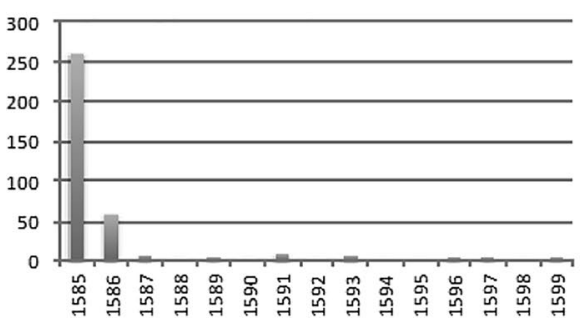

Cornet Sales by Year (208)

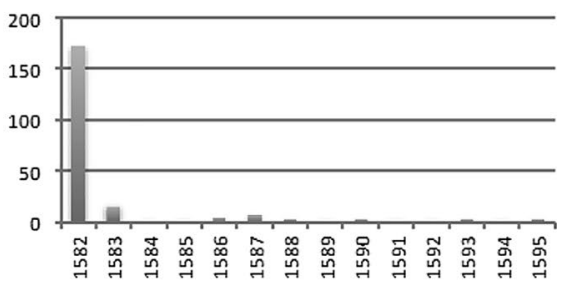

Pevernage Sales by Year (1326)

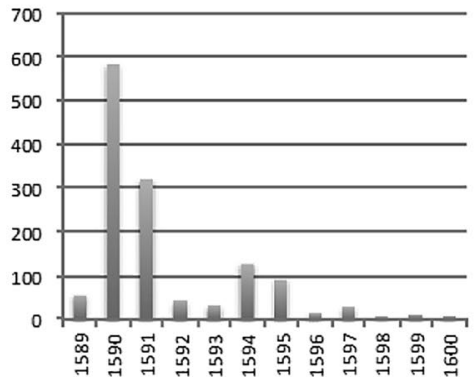

Figure 12.6 Plantin's partbook publications sales by year, 1578-1600 (2279 copies in total).

Gustavson also shows that copies of books printed by Egenolff still appeared in a catalogue from 1579, more than two decades after Egenolff's death, sitting in a warehouse and tying up capital. ${ }^{38}$ By contrast, most of Plantin's documented sales of music books were made shortly after publication. This was largely because he sent books to the Frankfurt fair as soon as possible after publication, which allowed him to shift stock quickly and thus release capital for further projects. This confirms Boorman's observation that 'publishers sent material to booksellers and their agents almost immediately on publication' ${ }^{39}$ Following the initial sales spike, partbooks realised only a few sales in the decade after publication. Only the partbooks of Pevernage's music (1589-1591) seem to match Boorman's hypothesis of a longer sales cycle, with small numbers of sales continuing until 1600 (see Figure 12.7).

Sales of choirbooks show a different pattern: after an initial burst of sales shortly after publication, there was usually a steady trickle of sales thereafter, more directly replicating Boorman's hypothesis. Perhaps this slower cycle of sale reflected the symbolic function of these publications, or the types of customers looking to purchase such editions. Colin Clair has found that ninety-one copies of the 1579 edition of Philippe de Monte's Missa Benedicta es remained in stock as late as $1640 .{ }^{40}$ Besides the consignments to the Frankfurt fair, where items were sold together purely on the basis of their publication date rather than their content, the choirbooks would also often be sold alongside other liturgical publications. Thus on 11 June 1579, Plantin sold two copies of La Hèle's Octo Missae to Sire Charles Pesnot's shop in Lyons, alongside 110 books of hours, 75 breviaries, 8 missals and other religious publications including 1 copy of the Psalterium for choir. ${ }^{41}$ 
De la Hèle Sales by Year (65)

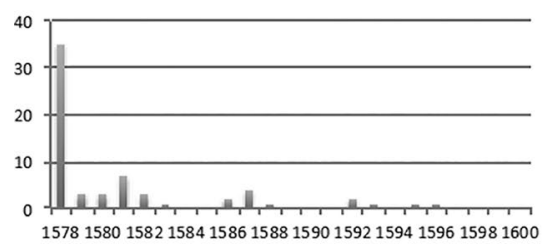

Du Gaucquier Sales by Year (32)

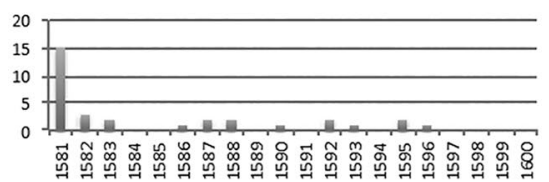

De Monte Benedicta Es Sales by Year (46)

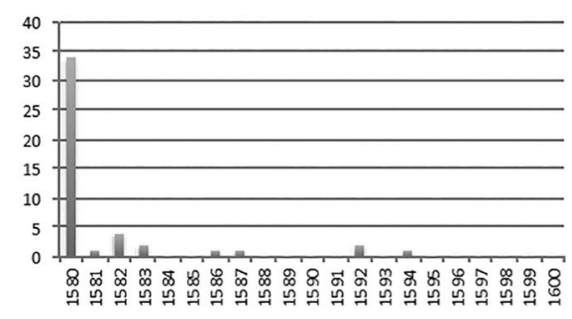

De Monte Liber I Masses Sales by Year

(38)

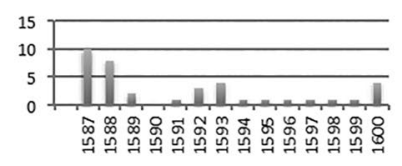

De Kerle Sales by Year (28)

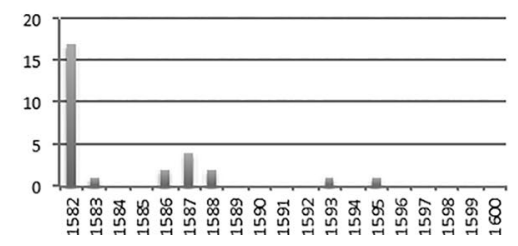

Figure 12.7 Plantin's choirbook publications sales by year, 1578-1600 (210 copies in total).

On 31 May 1580, Plantin sold three copies of De Monte's Missa Benedicta es in two separate transactions. The second consignment, which included two copies of De Monte's mass, also included seven missals, seven breviaries, six books of hours and numerous offices and other works, totalling seventy-six separate entries in all. ${ }^{42}$ On 14 October 1581, the same Fr. Andrea in Málaga purchased one copy of Du Gaucquier's Quatuor Missae alongside small numbers of breviaries and books of hours among other works. On 29 October 1587, Michel Sonnius, one of Plantin's favoured clients, purchased 285 books of hours, together with six copies of De Monte's Liber I Missarum. ${ }^{43}$ The polyphonic choirbooks and partbooks sent to the Jesuit College in Antwerp on 1 August 1586 constituted six out of a total of 201 items sent to aid the re-establishment of this religious educational institution. $^{44}$

Although these choirbooks were usually sold alongside other books of religious content, they were often of different format; some of the Books of Hours were produced in tiny $32^{\mathrm{mo}}$ format, suitable for carrying in a pocket. These examples remind us of the different structures for worship, and also that the customers of Plantin were often booksellers themselves, who acted as distributor to further destinations. The longevity for sales of the choirbooks could be due to the use of choirbooks as items for liturgical worship and the ongoing relevance of their content - in the seventeenth century, stile antico polyphony remained a prestigious language for liturgical music - just as was the case for the other religious and liturgical texts with which they were bought. 


\section{Plantin as an agent for other publishers}

The final element to analyse within these sales Journals are the entries relating to the sales of music books not published by the Officina Plantiniana. ${ }^{45}$ Voet has written that in 1566 Plantin sold books to the value of $16,340 \mathrm{fl}$., and that the purchases recorded in his accounts for the same year came to $6,109 \mathrm{fl}$., a figure just under a third of total sales. ${ }^{46}$ Voet is also prudent to note that 'this probably falls short of the real amount by some sum no longer exactly calculable', as the lists of purchases at the Frankfurt fair are likely incomplete. ${ }^{47}$ Between 1578 and 1600, the Officina Plantiniana sold 1,596 music books on behalf of other publishers, compared to total sales of 2,279 of its own partbooks and 210 of its own choirbooks. The musical publications from other publishers sold through the Officina Plantiniana were a mixture of sacred and secular music in partbook format, mainly popular publications printed in multiple editions.

The most popular titles included anthologies such as La fleur des chansons (RISM B/I $1592^{9}$ ), Harmonia celeste (RISM B/I 1583 ${ }^{14}$ ), Il lauro verde (RISM B/I 15918), Melodia olympica (RISM B/I 1591 ${ }^{10}$ ), Musica divina (RISM B/I 1583 ${ }^{15}$ ), Pratum Musicum (RISM B/I 1584 ${ }^{12}$ ) and Symphonia angelica (RISM B/I $1585^{19}$. All of these anthologies of motets or secular songs were produced by Jean Bellère and Pierre Phalèse the Younger, with the exception of $\mathrm{La}$ fleur des chansons d'Orlande de Lassus. This latter collection contained, in Richard Freedman's words, some of 'the most widely circulated and beloved musical works of sixteenthcentury Europe' ${ }^{48}$ Though these were compilations of music by various composers, Lassus' ongoing authority is reflected by the fact that Plantin's records sometimes name him in the records of sale of compilations in which he was only one contributor, such as the entry for Phalèse \& Bellère's Theatrum musicum (RISM B/I 1571 $\left.{ }^{16}\right)^{49}$ and La fleur des chansons d'Orlande de Lassus (RISM B/I 1596). ${ }^{50}$ Such compilations complemented the devotional and sacred music in Plantin's single-composer editions.

Just like Plantin's own partbooks, similar books published by other workshops and marketed through the Officina Plantiniana sold consistently within the Low Countries and subsequently furnished a strong ongoing trade. Significant numbers made their way to Plantin's strongest trading bases of Cologne, Danzig, Paris, London and the Frankfurt fair. By far the greatest number were sold within Antwerp; this is of particular interest, since the majority of publications he bought to sell on also came from Antwerp.

The publishers with whom Plantin traded significant quantities of stock were Jean Bogard, printer, bookseller and editor formerly in Louvain and now at Douai; and Jean Bellère and Pierre Phalèse the Younger, both printers, booksellers and editors in Antwerp. Plantin acted both as buyer from and as supplier to these businesses. Other booksellers to whom Plantin sold significant numbers of his own music publications included François Boulet in Lille, Nicolas Laurent in Tournai and Philippe Zanger in Louvain, while he sold smaller numbers to Joannes Masius in Ath, Job Matheuszoon in Utrecht and others.

Although Plantin often supplied books to individual customers, he purchased almost exclusively from other booksellers or publishers. ${ }^{51}$ Pierre Phalèse the Younger was Plantin's largest supplier; his titles amounted to $54.4 \%$ of Plantin's overall sales. Although much of the trade of Plantin's own music books went through Frankfurt, those which he sold for others were sold mainly from Antwerp, moving from there to an international clientele. These findings are made clear by Figure 12.8, which demonstrates the spread of destinations, in comparison to Figure 12.9, which shows that almost all the books that Plantin sold on behalf of other publishers were produced at Antwerp. 


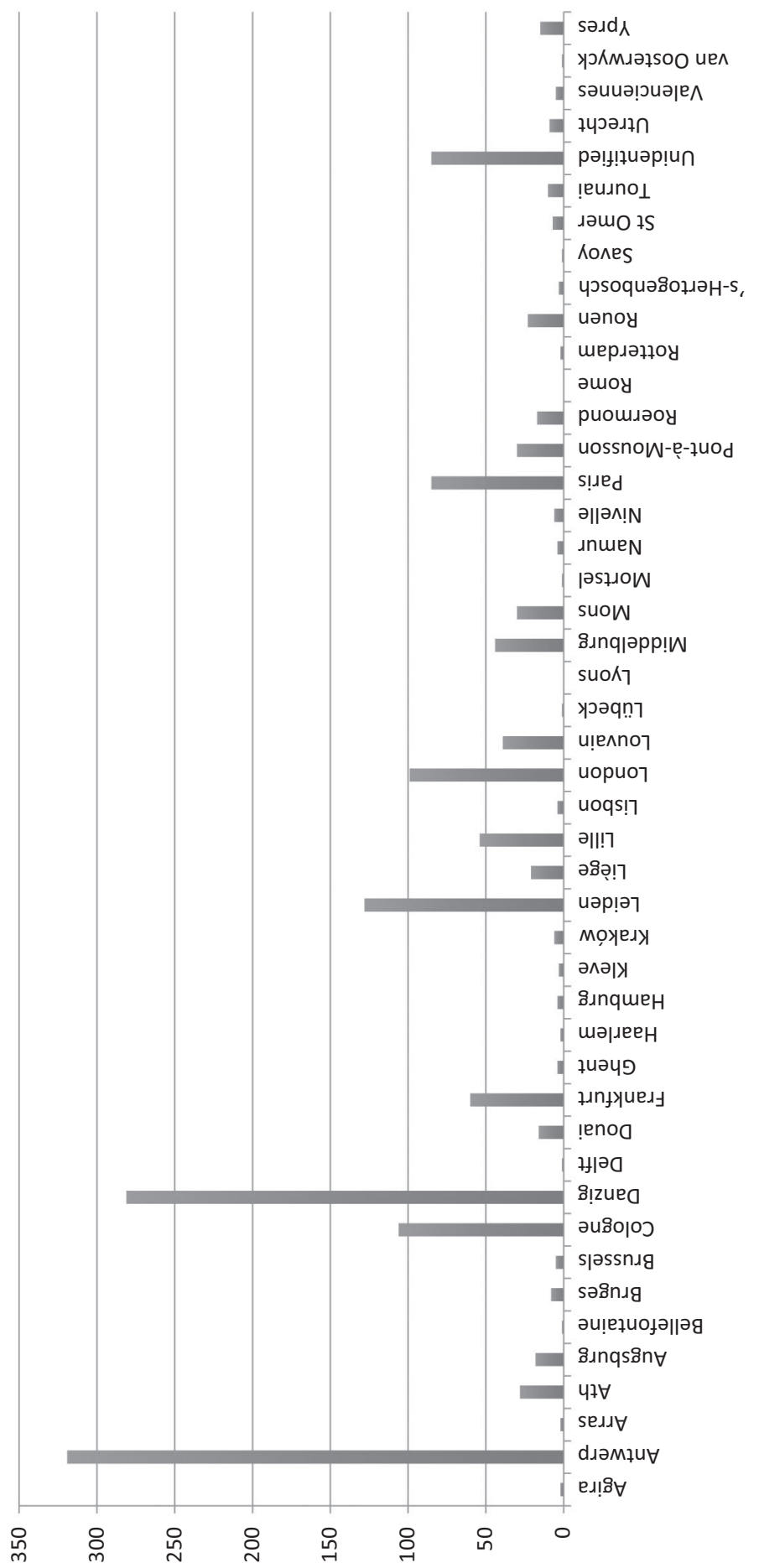

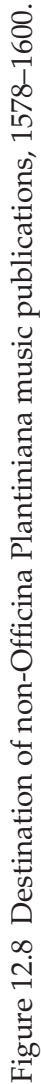




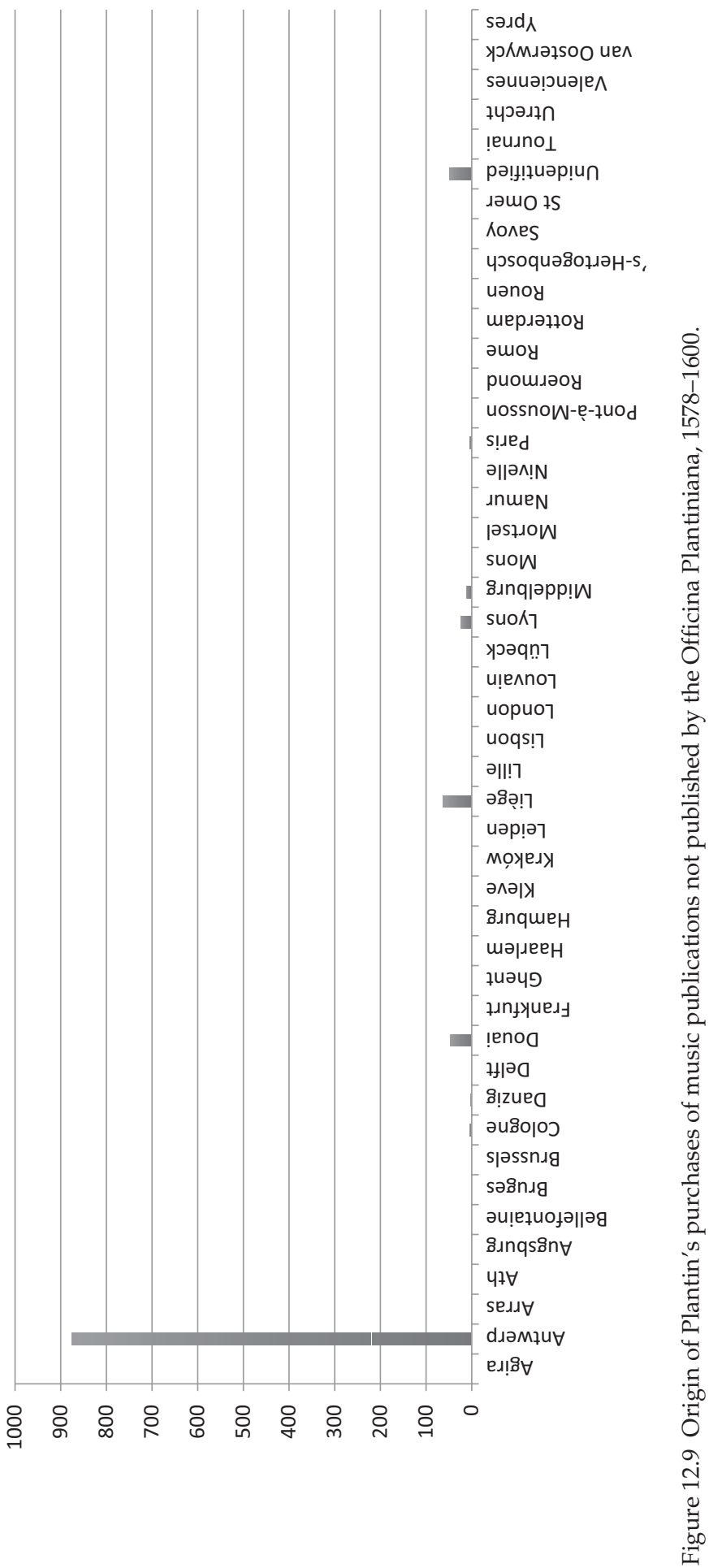


Table 12.5 provides the average price charged for some of the music publications by Phalèse and Bellère and sold through the Officina Plantiniana, according to the records at the Museum Plantin-Moretus. Both La fleur des chansons and the Symphonia angelica rose in price marginally in later editions. In 1587, Plantin charged 2 fl. 2 st. for a copy of the 1583 edition of Musica Divina printed on vellum. ${ }^{52}$ (Incidentally, this is one of the few instances in which a music book printed on parchment is mentioned in the sales accounts.) The highest degree of price variation is found for copies of the lute book Pratum Musicum, which was sold respectively for $1 \mathrm{fl} .3$ st., $1 \mathrm{fl} .4$ st., $1 \mathrm{fl} .5$ st., $1 \mathrm{fl} .8$ st. and $1 \mathrm{fl} .10$ st. The relatively high cost of production and subsequent sale price of this book resulted from the fact that it required specialist tablature, font and typesetting, and was printed in folio format. The prices Plantin charged for these music books of his contemporaries provide a useful context for the prices of Plantin's own music publications, which cost anywhere from a similar amount to double the amount per sheet. Again, such high prices may reflect the quality of paper, type and layout used.

Plantin's sales of music books typically comprised up to six copies of one or two titles. ${ }^{53}$ Exceptions to this tendency include the multiple titles of Plantin's choirbooks supplied to one customer, as already mentioned. The largest sale of music books through the Officina Plantiniana between 1578 and 1600 was 'Pour ... le memoire de Valentin Berisch' (bookseller in Danzig) on 30 September 1597. This sale included popular editions by Phalèse as well as editions of Marenzio and Gallo published by Gardano and Vincenti, Italian publications which Plantin likely found at the Frankfurt book fair. This Journal entry includes eighteen separate titles, demonstrating the importance of the Officina Plantiniana as intermediary for publishers from the Low Countries and the Italian peninsula to centres such as Danzig. ${ }^{54}$

The lower cost for de Castro's Tricinia matches its purpose as an educational publication, a genre of publication where affordability was at a premium. The higher cost of $1 \mathrm{fl}$. for the eight-voice madrigali collection was caused by the greater number of pages required for this publication. The relatively high price of $1 \mathrm{fl}$. for Le Rossignol musical des chansons is explained both by its popularity and once again the number of pages it contained. The most expensive publication in this list was Marenzio's Quinto libro de madrigali; its price was caused by the fact that it had six partbooks, one more than most others, and due to the transport costs from Italy. The Lassus publication La fleur des chansons d'Orlande de Lassus was also expensive, possibly because of his status and popularity. Many of the other publications, mainly collections of madrigals or chansons, were cheaper, fetching between 7 and 15 st.

The absence of any publications by Plantin in this particular sale is noticeable. Nevertheless, although the music books published by the Officina Plantiniana were generally more expensive than those of other publishers, the Officina still sold more of their own music publications than those of any other publisher. Rather than being a loss leader by printing a large volume of books as cheaply as possible, Plantin differentiated himself as a top-end printer, creating authority by publishing music books of the highest quality, thus creating his own market and reputation. ${ }^{55}$

\section{Conclusion}

The Journals of the Officina Plantiniana show that its sales of music books reached a wide international audience. Its customers included merchants, religious institutions and most of all, other booksellers. Despite what Voet has written about the prices of Plantin's 
general stock, the sale prices for music books generally remained consistent over time. Most sales of partbooks were made shortly after their publication date. Although choirbooks experienced the same initial spike, they also enjoyed slower but more steady sales subsequently. The rapid sale of partbooks the Officina Plantiniana contrasts with the findings of Royston Gustavson and Stanley Boorman on the slow sale of music books for German and Italian booksellers. It also reflects Plantin's role as publisher and desire to move stock onto other booksellers or to his base at the Frankfurt fair. Further studies of the sales records at the fairs might allow an alternative picture to emerge. The Officina Plantiniana also acted as intermediary for music books from other publishers; this is not unexpected, due to Plantin's number of contacts in the world of bookselling, both locally and internationally. Iain Fenlon and John Milsom have shown that imports of foreign music into England were controlled under privilege and licence by Thomas Tallis and William Byrd, awarded to them by Queen Elizabeth in 1575, but this data shows that other firms were also involved in the English trade. ${ }^{56}$ Finally, Plantin's sales at the Frankfurt book fair made up a large proportion of his music sales, as it was for other types of publications from his workshop. Plantin's Journals preserve data more detailed than what is available for any comparable music publisher of the time, and provide unique insights into the functioning of the music market.

Table 12.6 Plantin's polyphonic music books between 1578 and 1600

\begin{tabular}{|c|c|c|c|c|c|c|}
\hline Date & Composer & Title & Publisher & Sacred/secular & Size & RISM ID. \\
\hline 1578 & $\begin{array}{l}\text { George de La } \\
\text { Hèle }\end{array}$ & Octo Missae & Plantin & $\begin{array}{l}\text { Sacred } \\
\text { (Liturgical) }\end{array}$ & $\begin{array}{l}\text { Grand } \\
\text { Folio }\end{array}$ & A/I L 285 \\
\hline 1579 & $\begin{array}{l}\text { Philip de } \\
\text { Monte }\end{array}$ & $\begin{array}{l}\text { Missa } \\
\text { Benedicta es }\end{array}$ & Plantin & $\begin{array}{l}\text { Sacred } \\
\text { (Liturgical) }\end{array}$ & $\begin{array}{l}\text { Grand } \\
\text { Folio }\end{array}$ & A/I M 3315 \\
\hline 1579 & $\begin{array}{l}\text { Jacob de } \\
\text { Brouck }\end{array}$ & $\begin{array}{l}\text { Cantiones } \\
\text { sacrae }\end{array}$ & Plantin & $\begin{array}{l}\text { Both } \\
\text { (Devotional) }\end{array}$ & $\begin{array}{l}4^{\circ} \\
6 \mathrm{bks}\end{array}$ & A/I B 4613 \\
\hline 1581 & $\begin{array}{l}\text { Alard } \\
\text { Gauquier }\end{array}$ & Quatuor missae & Plantin & $\begin{array}{l}\text { Sacred } \\
\text { (Liturgical) }\end{array}$ & $\begin{array}{l}\text { Grand } \\
\text { Folio }\end{array}$ & A/I G 577 \\
\hline 1581 & $\begin{array}{l}\text { Séverin } \\
\text { Cornet }\end{array}$ & $\begin{array}{l}\text { Cantiones } \\
\text { musicae }\end{array}$ & Plantin & $\begin{array}{l}\text { Sacred } \\
\text { (Devotional) }\end{array}$ & $\begin{array}{l}4^{\circ} \\
6 \mathrm{bks}\end{array}$ & A/I C 3945 \\
\hline 1581 & $\begin{array}{l}\text { Séverin } \\
\text { Cornet }\end{array}$ & $\begin{array}{l}\text { Madrigali 5-8 } \\
\text { voci }\end{array}$ & Plantin & Secular & $\begin{array}{l}4^{\circ} \\
6 \mathrm{bks}\end{array}$ & A/I C 3947 \\
\hline 1581 & $\begin{array}{l}\text { Séverin } \\
\text { Cornet }\end{array}$ & $\begin{array}{l}\text { Chansons } \\
\text { françoyses }\end{array}$ & Plantin & Secular & $\begin{array}{l}4^{\circ} \\
6 \mathrm{bks}\end{array}$ & A/I C 3946 \\
\hline 1583 & $\begin{array}{l}\text { Jacobus de } \\
\text { Kerle }\end{array}$ & $\begin{array}{l}\text { Quatuor } \\
\text { Missae }\end{array}$ & Plantin & $\begin{array}{l}\text { Sacred } \\
\text { (Liturgical) }\end{array}$ & $\begin{array}{l}\text { Grand } \\
\text { Folio }\end{array}$ & A/I K 454 \\
\hline 1585 & $\begin{array}{l}\text { Claude le } \\
\text { Jeune }\end{array}$ & $\begin{array}{l}\text { Livre de } \\
\text { mélanges }\end{array}$ & Plantin & $\begin{array}{l}\text { Both } \\
\text { (Devotional) }\end{array}$ & $\begin{array}{l}4^{\circ} \\
6 \mathrm{bks}\end{array}$ & A/I L 1674 \\
\hline 1587 & $\begin{array}{l}\text { Philip de } \\
\text { Monte }\end{array}$ & $\begin{array}{l}\text { Missarum } \\
\text { liber I }\end{array}$ & Plantin & $\begin{array}{l}\text { Sacred } \\
\text { (Liturgical) }\end{array}$ & $\begin{array}{l}\text { Grand } \\
\text { Folio }\end{array}$ & A/I M 3320 \\
\hline 1589 & $\begin{array}{l}\text { Andreas } \\
\text { Pevernage }\end{array}$ & $\begin{array}{l}\text { Chansons... } \\
\text { livre premiere }\end{array}$ & $\begin{array}{l}\text { Plantin/ } \\
\text { Moretus }\end{array}$ & $\begin{array}{l}\text { Mainly sacred } \\
\text { (Devotional) }\end{array}$ & $\begin{array}{l}4^{\circ} \\
5 \mathrm{bks}\end{array}$ & A/I P 1670 \\
\hline 1590 & $\begin{array}{l}\text { Andreas } \\
\text { Pevernage }\end{array}$ & $\begin{array}{l}\text { Chansons... } \\
\text { livre second }\end{array}$ & Moretus & Mainly secular & $\begin{array}{l}4^{\circ} \\
5 \mathrm{bks}\end{array}$ & A/I P 1671 \\
\hline 1590 & $\begin{array}{l}\text { Andreas } \\
\text { Pevernage }\end{array}$ & $\begin{array}{l}\text { Chansons... } \\
\text { livre troisieme }\end{array}$ & Moretus & Mainly secular & $4^{\circ}$ & A/I P 1672 \\
\hline 1591 & $\begin{array}{l}\text { Andreas } \\
\text { Pevernage }\end{array}$ & $\begin{array}{l}\text { Chansons... } \\
\text { livre quatrieme }\end{array}$ & Moretus & Mainly secular & $4^{\circ}$ & A/I P 1673 \\
\hline
\end{tabular}




\section{Notes}

1 Plantin published approximately 2,450 titles in a thirty-four-year career as printer and publisher, whereby religious books were $33 \%$ and humanist books $35.5 \%$ of his total output. Percentages calculated from information provided in Voet, The Plantin Press, vol. 6.

2 Vanhulst, 'Suppliers and Clients of Christopher Plantin'.

3 The Journals are held at the Plantin-Moretus Museum in Antwerp. For an inventory of the Archives, see Denucé, Museum Plantin-Moretus. For a corresponding index to the inventory, see Coppens, 'The Plantin Moretus Archives'.

4 Both transactions by account and cash sales were integrated into the Journals.

5 Thanks to Saskia Willaert for offering her own transcriptions of these records for cross-reference.

6 Rooses, Correspondence de Plantin, 4: 158-163, no. 566.

7 Israel, Dutch Primacy, 28.

8 For a full catalogue of the polyphonic music publications from the Officina Plantiniana, see Stellfeld, Bibliographie.

9 Bowen and Imhoff, Christopher Plantin and Engraved Book Illustrations, 354-365.

10 Voet, The Golden Compasses, 2: 399.

11 Plantin-Moretus Museum, ARCH 60, 102v, 22 June 1582.

12 Plantin-Moretus Museum, ARCH 85, 349 .

13 Plantin-Moretus Museum, ARCH 10, 98v.

14 Plantin-Moretus Museum, ARCH 85, 353r.

15 Corr. II, no. 256 in Voet, The Golden Compasses, 2: 400.

16 Plantin produced the majority of liturgical books for the regions under Philip II's rule. See Costas, 'International Publishing'. One might argue that it was Plantin's desire to hold the printing monopoly that led to his commencing the publication of polyphonic music to curry more favour with the king.

17 For further information regarding owners and purchasers of books during the sixteenth century, see Chartier, 'Publishing Strategies and What People Read', in The Cultural Use of Print, 145-182.

18 There are entries for sales of some of Plantin's books of monophonic music to cathedrals, however. See Marianne Gillion, 'Musically Imposing: Plantin's Antiphonarium Romanum (1572-3) and its Reception in Antwerp Cathedral', presented at Print and Power, St Andrews Book History Conference, 22 June 2018; and eadem, 'Conciliating the Counter Reformation: The Plantin Processionals of 1574 and 1602', presented at the Renaissance Society of America 2019 Annual Conference, Toronto, 19 March 2019.

19 Plantin-Moretus Museum, ARCH 61, 123․

20 Plantin-Moretus Museum, ARCH 65, 157 . Thanks to Grantley McDonald for helping me to identify the abbey of Goailles in Salins.

21 Plantin's Psalterium (1571) cost $8 \mathrm{fl}$. for a copy printed on paper and $60 \mathrm{fl}$. for one on parchment. The page size of this book is half that of the choirbooks, but it is still in folio format. Plantin's Antiphonarium (1572/3) cost $17 \mathrm{fl}$. on ordinary paper, $19 \mathrm{fl}$. on best quality paper and $162 \mathrm{fl} .10 \mathrm{st}$. on parchment. Plantin's 1587 breviary, in quarto with ten illustrations, cost $6 \mathrm{fl}$. Voet states that Plantin sold his 1581 edition of Guicciardini's Descrittione di tutti i Paesi Bassi for $7 \mathrm{fl}$. with plates and 2 fl. 10 st. without (Voet, The Golden Compasses, 2: 381).

22 See Royston Gustavson's chapter in this book.

23 Boorman, 'Early Music Printing', 226.

24 Voet, The Golden Compasses, 2: 442.

25 Ibid.

26 Voet, The Golden Compasses, 2: 444.

27 For further discussion on pricing, see Gustavson, 'Competitive Strategy' and Gustavson, 'Commercialising the Choralis Constantinus'.

28 Extra charges for books printed on parchment or supplied with bindings are mentioned only a few times in the Journal accounts for this period.

29 Plantin-Moretus Museum, ARCH 58, 20v, 13 February 1580.

30 Plantin-Moretus Museum, ARCH 72, 193 ${ }^{\text {r-v }}, 17$ November 1595.

31 Kate van Orden has examined the books bound by the Officina Plantiniana before 1578, but this later period still awaits further research. Van Orden, Materialities, 58-66.

32 Plantin-Moretus Museum, ARCH 63, 71v. 
33 Gustavson, 'Competitive Strategy Dynamics', 191-192.

34 Van Orden states that Le Jeune was present in Antwerp during the siege of Anjou in 1583. Van Orden, Music, Discipline, and Arms, 4.

35 Six copies of De Brouck, ARCH 60, 61 v', twelve copies of De Kerle, ARCH 60, 102 ${ }^{v}$, fifty copies of Le Jeune to bookseller Arnold Mylius, ARCH 62, 140v, fifty-six mixed publications of Pevernage to Plantin's son-in-law Jan Spierinck, ARCH 67, 108 . The only consignments of Plantin's own publications sent to Frankfurt without a record of the price were for sixty and forty copies respectively of Cantiones Sever[ini] Cornetj $4^{\circ}$, both sent on 7 March 1582; for one copy of Misse de Monte sent in the Frankfurt envoy to Cologne on 14 August 1599 and twenty copies of Pevernage's Premier livre de chansons, sent on 21 December 1590; ARCH 60, 38v; ARCH 171, 112v'; and ARCH 67, $144^{\mathrm{v}}$ respectively.

36 This entry is from 1590.

37 Boorman, 'Thoughts on the Popularity', 138.

38 Gustavson, 'The Music Editions of Christian Egenolff', 173.

39 Boorman, 'Thoughts on the Popularity', 138.

40 Clair, Christopher Plantin, 147.

41 Plantin-Moretus Museum, ARCH 57, 84v.

42 Plantin-Moretus Museum, ARCH 58, 70 $-71^{\mathrm{v}}$.

43 Plantin-Moretus Museum, ARCH 59, 156 ; and ARCH 64, 137 respectively.

44 Plantin-Moretus Museum, ARCH 63, 70 ${ }^{\mathrm{r}}-72^{\mathrm{v}}$. For detailed entries for these extra publications, please see Hunter-Bradley, 'Polyphonic Music at the Officina'.

45 Voet, The Golden Compasses, 2:417.

46 Ibid.

47 Ibid.

48 Freedman, The Chansons of Orlando di Lasso, xiii.

49 Plantin-Moretus Museum, ARCH 58, 134 $4^{\mathrm{r}}$; ARCH 60, 30 ${ }^{\mathrm{r}}, 72^{\mathrm{v}}$.

50 Plantin-Moretus Museum, ARCH 69, 149 ${ }^{\mathrm{r}-\mathrm{v}}$; ARCH 70, 3v $, 55^{\mathrm{r}}, 85^{\mathrm{v}}$; ARCH 74, 64v, $144^{\mathrm{r}}$; ARCH 75, $100^{\mathrm{v}}, 190^{\mathrm{v}} ;$ ARCH 76, $48^{\mathrm{v}}$.

51 Information taken from these accounts as well as mentioned by Voet, The Golden Compasses, 2: 417.

52 Plantin-Moretus Museum, ARCH 64, 85".

53 See Appendix to Hunter-Bradley, 'Polyphonic Music at the Officina Plantiniana'.

54 Plantin-Moretus Museum, ARCH 74, 144 . This entry included three copies of Il trionfo di Dori descritto (RISM B/I 1596') at 12 st. per copy, three copies of Il vago alboreto di madrigali et canzoni (RISM B/I $1597^{15}$ ) at 14 st. per copy, three copies of La fleur des chansons d'Orlande de Lassus (RISM B/I 15967) at $1 \mathrm{fl} .10$ st. per copy, four copies of Melodia olympica (RISM B/I 15947) at $1 \mathrm{fl} .5$ st. per copy, three copies of Madrigali a otto voci (RISM B/I 1597'12) at 1 fl. per copy, one copy of Tricinia de Castro (RISM A/I C 1484) at 10 st. per copy and four copies of Le Rossignol musical des chansons (RISM B/I 159710) at $1 \mathrm{fl}$. per copy, all published by Pierre Phalèse. This consignment also included three copies of Di Luca Marenzio il settimo libro de madrigali a cinque voci (RISM B/I $1595^{10}$ ) at $1 \mathrm{fl} .6$ st. per copy and three copies of Di Luca Marenzio, il quinto libro de madrigali a sei voci (RISM $\mathrm{B} / \mathrm{I} 1595^{8}$ ) at $2 \mathrm{fl} .2$ st., both published by Antonio Gardano in Venice, and three copies of Il primo libro de madrigali di Gio. Pietro Gallo de Bari (RISM B/I 159720), published by Giacomo Vincenti, at 9 st. per copy. For detailed information regarding the publishers, number of pages and prices, see Hunter-Bradley, 'Polyphonic Music at the Officina Plantiniana', Chapter 5 and Appendix.

55 For information on publisher's positioning, see Gustavson, 'Competitive Strategy Dynamics', 202.

56 Fenlon and Milsom, 'Ruled Paper Imprinted', 139-140.

\section{References}

Bain, Susan E. 'Music Printing in the Low Countries in the Sixteenth Century'. Ph.D. dissertation, Cambridge University, 1974.

Boorman, Stanley. 'Early Music Printing: Working for a Specialized Market.' In Print and Culture in the Renaissance: Essays on the Advent of Printing in Europe, ed. Gerald P. Tyson and Sylvia S. Wagonheim. Newark: University of Delaware Press; London and Toronto: Associated University Presses, 1986, 222-245. 
Boorman, Stanley. 'Thoughts on the Popularity of Printed Music in the 16th-Century Italy'. Fontes Artes Musices 48 (2001): 129-144.

Boorman, Stanley. Studies in the Printing, Publishing and Performance of Music in the 16th Century. Aldershot: Ashgate, 2005.

Bowen, Karen L. Christopher Plantin's Books of Hours: Illustration and Production. Nieuwkoop: De Graaf Publishers, 1997.

Bowen, Karen L., and Dirk Imhof. Christopher Plantin and Engraved Book Illustrations in SixteenthCentury Europe. Cambridge: Cambridge University Press, 2008.

Chartier, Roger. The Cultural Use of Print in Early Modern France. Trans. Lydia G. Cochrane. Princeton, NJ: Princeton University Press, 1987.

Clair, Colin. Christopher Plantin. London: Cassell \& Company Ltd, 1960.

Clair, Colin. 'Christopher Plantin's Trade-Connexions with England and Scotland'. The Library, Fifth Series XIV (March 1959): 28-45.

Coppens, Christian. 'The Plantin Moretus Archives: An index to Jan Denucé's inventory of 1926'. De Gulden Passer 76-77 (1998-1999): 333-360.

Costas, Benito Rial. 'International Publishing and Local Needs: The Breviaries and Missals Printed by Plantin for the Spanish Crown'. In International Exchange in the European Book World, edited by Matthew McLean and Sara Barker. Boston, MA \& Leiden: Brill, 2014-2015, 15-30.

De Roover, Raymond. 'The Business Organisation of the Plantin Press in the Setting of SixteenthCentury Antwerp'. In Gedenkboek der Plantin-Dagen, 1555-1955. Antwerp: Vereniging der Antwerpsche Bibliophielen, 1956, 230-246.

Denucé, Jan. Museum Plantin-Moretus. Inventaris van het Plantynsch archief. Inventaire des archives Plantiniennes. Antwerp: Plantin-Moretus Museum, 1926.

Elder, Florence. 'Cost Accounting in the Sixteenth Century: The Books of Account of Christopher Plantin, Antwerp, Printer and Publisher'. Accounting Review 12.3 (1937): 226-237.

Fenlon, Iain. Music, Print and Culture in Early Sixteenth-Century Italy. The Panizzi Lectures 1994. London: The British Library, 1995.

Fenlon, Iain. 'Music, Print, and Society in Sixteenth-Century Europe'. In European Music, 1520-1640, edited by James Haar. Woodbridge: Boydell Press, 2006, 280-303.

Fenlon, Iain. 'Printed Polyphonic Choirbooks for the Spanish Market'. In Specialist Markets in the Early Modern Book World, edited by Richard Kirwan and Sophie Mullins. Leiden: Brill, 2015, 199-222.

Fenlon, Iain, and John Milsom. "Ruled Paper Imprinted": Music Paper and Patents in SixteenthCentury England'. Journal of the American Musicological Society 37 (1984): 139-163.

Flood, John L. 'The Frankfurt Fair in the Early Modern Period'. In Fairs, Markets and the Itinerant Book Trade, edited by Robin Myers, Michael Harris, and Giles Mandelbrote. Delaware: Oak Knoll Press / London: British Library, 2007, 1-42.

Forney, Kristine K. 'Antwerp's Role in the Reception and Dissemination of the Madrigal in the North'. In Atti del XIV Congresso della Società Internazionale di Musicologica. Trasmissone e recezione delle forme di cultura musicale, I: Round Table, edited by Lorenzo Bianconi et al. Turin: EDT, 1990, 239-253.

Forney, Kristine K. 'Music Patronage and the Rise of Bourgeois Culture in the Low Countries'. Revista de Musicología 16 (1993): 607-610.

Forney, Kristine K. 'Music, Ritual and Patronage at the Church of Our Lady, Antwerp'. Early Music History 7 (1987): 1-57. 
Forney, Kristine K. 'The Netherlands, 1520-1640'. In European Music: 1520-1640, edited by James Haar. Woodbridge: Boydell Press, 2006, 246-279.

Forney, Kristine K. 'Orlando di Lasso's 'Opus 1': The Making and Marketing of a Renaissance Music Book'. Revue belge de Musicologie 39/40 (1985/1986): 33-60.

Freedman, Richard. The Chansons of Orlando Di Lasso and their Protestant Listeners: Music, Piety and Print in Sixteenth-Century France. Rochester, NY: University of Rochester Press, 2001.

Fudge, John D. Commerce and print in the early Reformation. Leiden: Brill, 2007.

Giselbrecht, Elisabeth. 'Crossing Boundaries: the printed Dissemination of Italian Sacred Music in German-speaking Areas (1580-1620)'. PhD dissertation, University of Cambridge, 2012.

Gross, Anne T. 'The Firm of Phalèse: A Modest Venture'. Music Printing in Antwerp and Europe in the 16th Century. Yearbook of the Alamire Foundation 2 (1997): 269-278.

Gustavson, Royston. 'Commercialising the Choralis Constantinus: The Printing and Publishing of the First Edition'. In Heinrich Isaac and Polyphony for the Proper of the Mass in the Late Middle Ages and Renaissance, edited by David J. Burn and Stefan Gasch. Turnhout: Brepols, 2011, 215-268.

Gustavson, Royston. 'Competitive Strategy Dynamics in the German Music Publishing Industry 1530-1550'. In NiveauNischeNimbus: Die Anfänge des Musikdrucks nördlich der Alpen, edited by Birgit Lodes. Wiener Forum für ältere Musikgeschichte 3. Tutzing: Hans Schneider, 2010, 185-210.

Gustavson, Royston. 'The Music Editions of Christian Egenolff: A New Catalogue and Its Implications'. In Early Music Printing in German-Speaking Lands, edited by Andrea Lindmayr-Brandl, Elisabeth Giselbrecht and Grantley McDonald. London and New York: Routledge, 2018, 153-195.

Hammond, Susan L. 'Producing Madrigal Books at the Phalèse Print Shop'. Yearbook of the Alamire Foundation 6 (2008): 225-249.

Hunter-Bradley, Louisa. 'Polyphonic Music at the Officina Plantiniana: Commissioning, Production, Format and Sales through Christopher Plantin and his Heirs (1578-1600)'. PhD Dissertation, Royal Holloway University of London (in preparation).

Imhof, Dirk. Jan Moretus and the Continuation of the Plantin Press: A Bibliography of the Works Published and Printed by Jan Moretus I in Antwerp (1589-1610). Leiden: Brill/Hes \& De Graaf, 2014.

Israel, Jonathan I. Dutch Primacy in World Trade, 1585-1740. Oxford: Clarendon Press, 1989.

Maclean, Ian. 'The Market for Scholarly Books and Conceptions of Genre in Northern Europe. 15701630'. In Die Renaissance im Blick der Nationen Europas, edited by George Kauffman. Wiesbaden: Harrassowitz, 1989, 17-31.

Milsom, John, ed. Thomas Tallis and William Byrd, Cantiones sacrae 1575. Early English Church Music vol. 56. London: Stainer and Bell, 2014.

Pettegree, Andrew and Malcolm Walsby, eds. Netherlandish Books Published in the Low Countries and Dutch Books Published Abroad Before 1601. Leiden: Brill, 2011.

Rooses, Max and Jan Denucé. Correspondance de Christophe Plantin, 8 vols. Antwerp: J. E. Buschmann, 1883-1918.

Rose, Stephen. 'The Mechanisms of the Music Trade in Central Germany, 1600-40'. Journal of the Royal Musical Association 130 (2005): 1-37.

Ruppel, Aloys. 'Die Bücherwelt des 16. Jahrhunderts und die Frankfurter Büchermessen'. In Gedenkboek der Plantin-Dagen, 1555-1955. Antwerp: Vereniging der Antwerpsche Bibliophielen, 1956, 146-165.

Simpson, Julianne. 'Selling the Biblia Regia: The Marketing and Distribution Methods for Christopher Plantin's Polyglot Bible'. In Books for Sale: The Advertising and Promotion of Print Since the 
Fifteenth Century, edited by Robyn Myers, Michael Harris, and Giles Mandelbrote. New Castle, DE: Oak Knoll Press, 2009, 27-55.

Stellfeld, Jean A. Bibliographie des Éditions Musicales Plantiniennes. Brussels: Palais Des Académies, 1949.

van Orden, Kate, ed. Music and the Cultures of Print, afterword by Roger Chartier. New York: Garland Publishing, 2000.

van Orden, Kate. Music, Discipline, and Arms in Early Modern France. Chicago, IL: University of Chicago Press, 2004.

van Orden, Kate. Music, Authorship, and the Book in the First Century of Print. Berkeley: University of California Press, 2014.

Vanhulst, Henri. Catalogue des éditions de musique publiées à Louvain par Pierre Phalèse et ses fils 15451578. Brussels: Palais des Académies, 1990.

Vanhulst, Henri. 'The Distribution of Printed Polyphonic Music in the Low Countries at the End of the 16th and the Beginning of the 17th Century'. In Musique et société: Hommages à Robert Wangermé, edited by Henri Vanhulst and Malou Haine. Brussels: Edition de l'Université de Bruxelles, 1988, 27-51.

Vanhulst, Henri. 'Suppliers and Clients of Christopher Plantin, Distributor of Polyphonic Music in Antwerp (1566-1578)'. In Musicology and Archival Research: Colloquium Proceedings, 22-23.4.1993, edited by Barbara Haggh, Frank Daelemans, and André Vanrie. Brussels: Archives Générales du Royaume, 1994, 558-604.

Voet, Leon. The Golden Compasses: A History and Evaluation of the Printing and Publishing Activities of the Officina Plantaniana at Antwerp in Two Volumes. Amsterdam: Vagendt, 1969-1972.

Voet, Leon. The Plantin Press (1555-1589): A Bibliography of the Works Printed and Published by Christopher Plantin at Antwerp and Leiden. 6 vols. Amsterdam: Van Hoeve, 1980-1983.

Wagner, Lavern J. 'Music of the Composers from the Low Countries at the Spanish Court of Philip II'. In Musique des Pays-Bas anciens - musique espagnole ancienne (ca. 1450-ca. 1650): Actes du Colloque musicologique international, Bruxelles, 28-29 X 1985, edited by Paul Becquart and Henri Vanhulst. Louvain: Peeters, 1988, 193-214.

Wathey, Andrew B. 'Musicology, Archives and Historiography'. In Musicology and Archival Research, edited by Barbara Haggh et al. Brussels: Archives et Bibliothèques de Belgique, 1994, 3-26. 